\title{
Potensi Konflik Lahan Perkebunan Kelapa Sawit
}

\author{
Riyadi Mustofa (iD*, Riati Bakce \\ STIE Persada Bunda \\ * riyadimustofa@gmail.com
}

\begin{abstract}
Abstrak. Potensi konflik lahan di Provinsi Riau 1.972.699 ha yang terdiri dari konflik di kawasan hutan lindung, hutan produksi konversi, hutan produksi terbatas dan kawasan konservasi. Konflik tersebut karena pluralisme hukum antara pemerintah dengan masyarakat, pemerintah dengan koporasi, dan korporasi dengan masyarakat. Konflik tersebut akan semakin bertambah seiring dengan meningkatnya kebutuhan lahan oleh masyarakat untuk kepentingan ektensifikasi lahan perkebunan kelapa sawit. Tujuan penelitian ini adalah mendeskripsikan konflik lahan yang terjadi berdasarkan status kawasan, pola ruang, perizinan dan pemanfaatan lahan untuk perkebunan kelapa sawit serta pihak yang terlibat didalamnya. Metode penelitian yang digunakan adalah dengan melakukan overlay berbagai peta. Hasil overlay selanjutnya ditabulasi dan didiskripsikan berdasarkan kriteria peta konflik. Hasil penelitian menunjukan bahwa berdasarkan peta tutupan lahan, konflik lahan perkebunan mencapai 51,19\% dan pertanian lahan kering campur semak termasuk didalamnya perkebunan kelapa sawit rakyat 40,42\%. Kesimpulan bahwa potensi konflik lahan terbesar berada lahan perkebunan kelapa sawit baik yang dikuasai korporasi maupun mayarakat sebagai perkebunan kelapa sawit rakyat sehingga sulit mendapatkan legalitas lahan.
\end{abstract}

Kata Kunci: konflik lahan, perkebunan, kelapa sawit

\section{PENDAHULUAN}

Konflik lahan di Indonesia merupakan kasus yang terjadi sejak zaman kemerdekaan, dimana sejarah menunjukan bahwa hingga saat ini masih terdapat sengkete batas Negara, Provinsi, Kabupaten, Kecamatan hingga perebutan batas Desa. Tumpang tindih penguasaan tanah di Indonesia mayoritas terjadi akibat adanya legal pluralism (Larson, 2012), yang menyebabkan situasi sistem hukum berinteraksi dalam satu kehidupan social, sehingga kedua hukum yang berbeda dalam masyarakat dan pemerintah terjadi saling klaim hak atas tanah/hutan.

Pemrintah melalui Badan Pertanahan Nasional (BPN) telah berupaya memberi skema dalam penyelesaian konflik lahan yang terjadi secara vertical dan horizontal. Tahun 2011 BPN telah menerima pengaduan 3.500 konflik lahan yang didominasi sengketa masyarakat dengan perusahaan kelapa sawit (Colchester dan Chao, 2011). Konflik tersebut terjadi tidak hanya disebabkan oleh tidak adanya pengetahuan masyarakat tentang penguasaan lahan dan keserakahan dalam menguasai lahan sehingga terjadi tumpeng tindih lahan atas berbagai kepentingan.

Setelah ditetapkanya Rencana Tata Ruang Wilayah Provinsi Riau pada tahun 2018 melalui Peraturan Daerah (Perda) No. 10 Tahun 2018. Meskipun RTRW telah disahkan menjadi Perda tidak secara otomatis semua permasalahan sengketa atau konflik lahan selesai. Saat ini konflik lahan masih terus terjadi dan diperkirakan jumlahnya akan semakin meningkat seiring dengan bertambahnya kebutuhan lahan oleh masyarakat. Astuti (2011) menyatakan bahwa pada era reformasi agraria kasus konflik lahan terus terjadi dan terus meningkat jumlahnya. Kementerian Lingkungan Hidup dan Kehutanan mencatat bahwa potensi konflik lahan di kawasan hutan Provinsi Riau seluas 1.972.699 ha. Konflik tersebut terjadi diguga akibat tidak tegasnya aparat penegak hukum dalam melakukan sosialisasi tentang penunjukan, penataan batas, pemetaan, dan penetapan kawasan hutan.

Masyarakat pada umunya tidak memahami dan mengetahui tentang kawasan hutan, sehingga lahan yang dikuasainya selama bertahun-tahun masuk dalam kawasan hutan dalam sebagian besar tidak mengetahuinya. Selain itu, pemerintah dan korporasi pemegang izin tidak melaksanakan kewajiban secara utuh terutama dalam tatabatas dan minimnya pelaksanaan monitoring serta evaluasi terhadap kawasan hutan. Pembangunan infrastruktur dan fasilitas umum yang dilakukan oleh pemerintah turut menyumbang terbukanya akses menuju kawasan hutan, secara tidak langsung turut andil dalam okupasi lahan yang menjadi pemicu To cite this article: Mustofa, R., dan R. Bakce. 2019. Potensi Konflik Lahan Perkebunan Kelapa Sawit. Unri Conference Series: Agriculture and Food Security 1: 58-66. https://doi.org/10.31258/unricsagr.1a8 
terjadinya konflik lahan. Konflik yang terjadi tidak hanya antara masyarakat dengan masyarakat atau masyarakat dengan pemerintah, akan tetapi konflik juga terjadi perebutan lahan perusahaan oleh masyarakat (Mutolib et al., 2015).

Keberhasilan masyarakat dalam menguasai lahan menjadi arena pasar yang menarik karena tingginya permintaan lahan untuk perkebunan, alih fungsi lahan dari lahan pertanian maupun dari peruntukan lainya belum memenuhi permintaan tersebut. Transaksi pada lahan konflik terjadi secara terang-terangan oleh masyarakat adat sebagai penguasa tanah ulayat dengan masyarakat luar dalam skala masif dan terus menerus (Mutolib et al., 2015). sehingga masyarakat adat terancam kehilangan tanah ulayatnya dan dikuasai oleh pendatang.

Tujuan penelitian ini adalah mendeskripsikan konflik lahan yang terjadi berdasarkan peta RTRW meliputi status kawasan, pola ruang, perizinan dan pemanfaatan lahan untuk perkebunan kelapa sawit serta pihak yang terlibat didalamnya dan faktor-faktor penyebab terjadinya konflik dalam penggunaan kawasan hutan. Selanjutnya mendiskripsikan kondisi lahan yang telah menjadi lahan perkebunan kelapa sawit meliputi luas lahan, produkstivitas dan jumlah petani pekebun yang terlibat didalamnya dampak dari konflik tersebut.

\section{KAJIAN PUSTAKA}

\section{Konflik}

Konflik atau sengketa adalah merupakan realitas sosial yang dapat terjadi dimana saja dan kapan saja. Sebagai suatu realitas sosial konflik atau sengketa agar tidak bersifat anarkis, maka perlu dicarikan solusi penyelesaian Apabila menilik sengketa khususnya sengketa pertanahan yang terjadi dewasa ini, sebenarnya jenisnya sangatlah berbeda dengan sengketa-sengketa perdata pada umumnya. Karena di dalamnya telah terdapat pertalian berbagai unsur-unsur dan permasalahan seperti hukum, politik, ekonomi, sosial dan budaya.

Kompleknya unsur-unsur dan berbagai permasalahan tersebut seringkali tidak bisa dipilah-pilah sehingga mempersulit untuk mencari pemecahan nya. Maraknya kegiatan non kehutanan di dalam kawasan hutan, kerap menimbulkan berbagai konflik antar sektor maupun antar masyarakat, pemerintah dan swasta sebagai investor atau yang membiayai dalam proses perambahan lahan.

Konflik lahan merupakan suatu kasus pertanahan berupa sengketa, konflik, atau perkara pertanahan yang disampaikan kepada Badan Pertanahan Nasional Republik Indonesia untuk mendapatkan penanganan, penyelesaian sesuai ketentuan peraturan perpu dan kebijakan pertanahan Nasional (Peraturan Kepala BPN RI nomor 3 tahun 2011 Tentang Pengelolaan Pengkajian dan Penanganan Kasus Pertanahan).

Berbagai jenis atau tipologi kasus atau konflik lahan dapat dikategorikan sebagai meliputi (1) kasus-kasus berkenaan dengan penggarapan rakyat atas tanah-tanah perkebunan, kehutanan dan lain-lain; (2) Kasuskasus berkenaan dengan ekses-ekses penyediaan tanah untuk pembangunan; (3) Sengketa perdata berkenaan dengan masalah tanah; dan (4) Sengketa berkenaan dengan tanah ulayat. Konflik tanah paling banyak terjadi di daerah yang secara perekonomiannya sedang bertumbuh, dan daerah yang memiliki hutan luas dan area perkebunan seperti di daerah Sumatera, Kalimantan, dan Jawa (Walhi).

\section{Lahan}

Lahan merupakan sebagai suatu wilayah di permukaan bumi, mencakup semua komponen biosfer yang dapat dianggap tetap atau bersifat siklis yang berada di atas dan di bawah wilayah tersebut, termasuk atmosfer, tanah, batuan induk, relief, hidrologi, tumbuhan dan hewan, serta segala akibat yang ditimbulkan oleh aktivitas manusia di masa lalu dan sekarang yang kesemuanya itu berpengaruh terhadap penggunaan lahan oleh manusia pada saat sekarang dan di masa mendatang (Brinkman dan Smyth, 1973; dan FAO, 1976). Lahan dapat dipandang sebagai suatu sistem yang tersusun atas (i) komponen struktural yang sering disebut karakteristik lahan, dan (ii) komponen fungsional yang sering disebut kualitas lahan. Kualitas lahan ini pada hakekatnya merupakan sekelompok unsur-unsur lahan (complex attributes) yang menentukan tingkat kemampuan dan kesesuaian lahan (FAO, 1976).

FAO (1976) dalam Rayes (2007) lahan memiliki banyak fungsi yaitu fungsi produksi, lingkungan biotik, pengatur iklim, hidrologi, penyimpanan, pengendali sampah dan polusi, ruang kehidupan, peninggalan dan penyimpanan, dan penghubung spasial. Pemanfaatan lahan seharusnya memiliki keseimbangan dari semua fungsi, tujuanya agar tidak terjadi melebihi daya dukung dan daya tamping. Tutupan lahan merupakan tutupan biofisik yang dapat diamati merupakan hasil pengaturan, aktivitas dan aktivitas manusia yang 
dilakukan pada kenis penutupan lahan tertentu untuk melakukan kegiatan produksi, perubahan, ataupun perawatan pada penutupan lahan tersebut.

\section{Hutan}

Hutan merupakan kumpulan flora dan fauna yang didominasi pepohonan besar yang berfungsi sebagai tempat perlindungan ekosistem dan keanekaragaman hayati. Hutan adalah suatu kesatuan ekosistem berupa hamparan lahan berisi sumber daya alam hayatiyang didominasi pepohonan dalam persekutuan alam lingkungannya, yang satu dengan lainnya tidak dapat dipisahkan (Undang-Undang Republik Indonesia Nomor 41 Tahun 1999 Tentang Kehutanan). Hutan dapat dimanfaatkan oleh setiap orang atau warga negara yang bertindak secara orang perseorangan atau korporasi. Pemanfaatan hutan bertujuan untuk memperoleh manfaat yang optimal bagi kesejahteraan seluruh masyarakat secara berkeadilan dengan tetap menjaga kelestariannya. (UU No. 18 Tahun 2013 tentang Pencegahan dan Pemberantasan Perusakan Hutan).

Selain dapat dimanfaatkan oleh manusia, hutan memliki fungsi konservasi, fungsi lindung, dan fungsi produksi. Fungsi lindung diperuntukan bagi kawasan hutan yang mempunyai fungsi pokok sebagai perlindungan sistem penyangga kehidupan untuk mengatur tata air, mencegah banjir, mengendalikan erosi, mencegah intrusi air laut, dan memelihara kesuburan tanah. Fungsi konserfasi diperuntukan bagi kawasan hutan dengan ciri khas tertentu, yang mempunyai fungsi pokok pengawetan keanekaragaman tumbuhan dan satwa serta ekosistemnya. Dan fungsi produksi diperuntukan bagi hutan yang mempunyai fungsi pokok memproduksi hasil hutan. Selain ketiga fungsi diatas, hutan memliki fungsi untuk melakukan keseimbangan oksigen dan karbon dioksida, serta untuk mempertahankan kesuburan tanah, keseimbangan tata air wilayah dan kelestarian daerah dari erosi (Arief, 2001).

\section{Kawasan hutan}

Kawasan hutan adalah wilayah tertentu yang ditunjuk dan atau ditetapkan oleh Pemerintah untuk dipertahankan keberadaannya sebagai hutan tetap. Kawasan hutan terdiri dari hutan tetap, hutan produksi, tetap, hutan produksi tetap, hutan produksi terbatas, dan hutan produksi yang dapat dikonversi.

Hutan tetap adalah kawasan hutan yang akan dipertahankan keberadaannya sebagai kawasan hutan, terdiri dari hutan konservasi, hutan lindung, hutan produksi terbatas, dan hutan produksi tetap. Hutan Produksi Tetap yang selanjutnya disebut HP, adalah kawasan hutan dengan faktor-faktor kelas lereng, jenis tanah, dan intensitas hujan setelah masing-masing dikalikan dengan angka penimbang mempunyai jumlah nilai dibawah 125, di luar kawasan lindung, hutan suaka alam, hutan pelestarian alam, dan taman buru.

Hutan Produksi Terbatas yang selanjutnya disebut HPT, adalah kawasan hutan dengan faktor-faktor kelas lereng, jenis tanah, dan intensitas hujan setelah masingmasing dikalikan dengan angka penimbang mempunyai jumlah nilai antara 125-174, di luar kawasan lindung, hutan suaka alam, hutan pelestarian alam, dan taman buru. Hutan Produksi yang dapat Dikonversi yang selanjutnya disebut HPK adalah kawasan hutan yang secara ruang dicadangkan untuk digunakan bagi pembangunan di luar kegiatan kehutanan.

\section{Sistem Informasi Geografis (SIG)}

Sistem Informasi Geografis (SIG) atau Geographic Information System(GIS) sebagai salah satu perangkat lunak yang memiliki kelebihan karena kemampuannya membuat "link" atau hubungan antara feature spatial (titik, garis dan polygon) dengan data atributnya yang tersimpan dalam suatu basis data. SIG sebagai suatu komponen yang terdiri dari perangkat keras, perangkat lunak, data geografis dan sumberdaya manusia yang bekerja bersama secara efektif untuk memasukan, menyimpan, memperbaiki, memperbaharui, mengelola, memanipulasi, mengintegrasikan, menganalisa dan menampilkan data dalam suatu informasi berbasis geografis (Prahasta, 2003).

Kemampuan atau kelengkapan dalam basis utama merupakan ciri utama yang mencerminkan kemampuan dari SIG itu sendiri. Barus dan Wiradisastra (2000) juga mengungkapkan bahwa SIG adalah alat yang handal untuk menangani data spasial, dimana dalam SIG data dipelihara dalam bentuk digital sehingga data ini lebih padat dibanding dalam bentuk peta cetak, tabel atau dalam bentuk konvensional lainnya yang akhirnya akan mempercepat pekerjaan dan meringankan biaya yang diperlukan. Dengan demikian dapat dikatakan bahwa basis data adalah komponen utama dari SIG.

Arronoff (1989), mendefinisikan SIG sebagai suatu sistem berbasis komputer yang memiliki kemampuan dalam menangani data bereferensi geografi yaitu pemasukan data, manajemen data (penyimpanan dan pemanggilan kembali), manipulasi dan analisis data, serta keluaran sebagai hasil akhir (output). Hasil akhir dapat dijadikan acuan dalam pengambilan keputusan pada masalah yang berhubungan dengan geografi. Selanjutnya SIG merupakan sistem yang dapat mendukung pengambilan keputusan spasial dan mampu 
mengintegrasikan deskripsi- deskripsi lokasi dengan karakteristik-karakteristik fenomena yang ditemukan di lokasi tersebut.

Fungsi SIG untuk memasukan, menyimpan, mengelola, menganalisis dan mengaktifkan kembali data yang mempunyai referensi keruangan untuk berbagai tujuan yang berkaitan dengan pemetaan dan perencanaan. SIG terdiri atas beberapa subsistem yaitu data input, data output, data management, data manipulasi dan analisis hingga layout dari data. Data yang dapat dilakukan analisis adalah data yang berorientasi geografis dan merupakan lokasi yang memiliki sistem koordinat tertentu, sebagai dasar referensinya. Sehingga aplikasi SIG dapat menjawab beberapa pertanyaan seperti; lokasi, kondisi, trend, pola dan pemodelan (Prahasta, 2006).

\section{Overlay}

Overlay merupakan suatu sistem informasi dalam bentuk grafis yang dibentuk dari penggabungan berbagai peta individu (memiliki informasi/database yang spesifik). Overlay peta dilakukan minimal dengan 2 jenis peta yang berbeda secara teknis dikatakan harus ada polygon yang terbentuk dari 2 jenis peta yang dioverlaykan. Jika dilihat data atributnya, maka akan terdiri dari informasi peta pembentukya (Prahasta, 2006). Overlay dilakukan terhadap peta potensi konflik, RTRWP, kawasan hutan, perizinan, tutupan lahan, perkebunan.

Masing-masing peta tranparansi memberikan informasi tentang komponen lingkungan dan sosial. Peta komposit yang terbentuk akan memberikan gambaran tentang konflik antara proyek dan faktor lingkungan. Metode ini tidak menjamin akan mengakomodir semua dampak potensial, tetapi dapat memberikan dampak potensial pada spasial tertentu (Prahasta, 2006). Selanjutnya dilakukan join tabel antara peta hasil overlay dengan data Statistik Perkebunan Provinsi Riau. Data tersebut dilakukan tabulasi dan analisis terhadap masing masing peta tematik pada setiap layer peta.

\section{Peta}

Peta adalah suatu gambaran dari unsur-unsur alam dan/atau buatan manusia, yang berada di atas maupun di bawah permukaan bumi yang digambarkan pada suatu bidang datar dengan skala tertentu (Perpres No. 9 Tahun 2016 Tentang Pelaksanaan Kebijakan Satu peta Tingkat Ketelitian Skala 1: 50.000). Peta adalah suatu representasi atau gambaran unsur-unsur atau kenampakan abstrak yang dipilih dari permukaan bumi atau benda-benda angkasa dan umumnya digambarkan pada satu bidang datar dan diperkecil atau diskalakan.

Proses pemetaan yaitu tahapan-tahapan yang harus dilakukan dalam perancangan sebuah peta. Pelaksanaan pembuatan peta meliputi tiga tahapan yaitu Tahap pengumpulan data, Tahap penyajian data, dan tahap penggunaan peta. Pemetaan dilakukan sebagai sarana penyedia informasi spasial terintegrasi dan terkini untuk analisis keruangan. Peta dapat memberi kepastian usaha terutama terkait lokasi, peruntukan/zonasi lahan, memperjelas proses perizinan dan lainya.

\section{Perkebunan}

Perkebunan adalah segala kegiatan pengelolaan sumber daya alam, sumber daya manusia, sarana produksi, alat dan mesin, budi daya, panen, pengolahan, dan pemasaran terkait tanaman Perkebunan. Lahan perkebunan adalah bidang tanah yang digunakan untuk usaha perkebunan. Tanah adalah permukaan bumi, baik yang berupa daratan maupun yang tertutup air dalam batas tertentu sepanjang penggunaan dan pemanfaatannya terkait langsung dengan permukaan bumi, termasuk ruang di atas dan di dalam tubuh bumi (Undang-undang No. 39 Tahun 2014 Tentang Perkebunan).

Pekebun adalah orang perseorangan warga negara Indonesia yang melakukan Usaha Perkebunan dengan skala usaha tidak mencapai skala tertentu. Selanjutnya perkebunan kelapa sawit merupakan salah satu komoditas perkebunan strategis tertentu yang memiliki peranan penting dalam pembangunan sosial, ekonomi dan lingkungan hidup. Oleh sebab itu menjadi magnet bagi masyarakat dan perusahaan perkebunan melakulan usahatani dan budidaya perkebunan dalam memperoleh nilai tambah.

\section{METODE}

Penelitian ini dilakukan di wilayah Provinsi Riau, pemilihan lokasi atas pertimbangan bahwa Provinsi Riau memiliki perkebunan kelapa sawit terluas di Indonesia dan maraknya konflikdan okupasi lahan yang terjadi di kawasan hutan. Provinsi Riau baru saja memiliki Perda No 10 tentang RTRW sebagai kepastian hokum atas struktur dan pola ruang, karena dalam rentang waktu delapan belasa tahun tanpa RTRW. Pertimbangan lainya terdapat berbagai kegiatan non kehutanan, seperti adanya pemerintahan kecamatan dan desa yang 
definitif, pemukiman dan sarana prasarana masyarakat serta pemerintah Kecamatan/Desa diikuti pembangunan infrastruktur milik pemerintah, Badan Usaha Milik Negara dan Swasta.

Pendekatan penelitian ini menggunakan metode kualitatif deskriptif. Moleong (2007) menjelaskan bahwa penelitian kualitatif adalah penelitian yang bermaksud untuk memahami fenomena tentang apa yang dialami oleh subjek penelitian secara holistik (utuh) dan dengan cara deskripsi dalam bentuk katakata dan bahasa pada suatu konteks khusus yang alamiah, serta dengan memanfaatkan berbagai metode alamiah yang salah satunya bermanfaat untuk keperluan meneliti dari segi prosesnya.

Metode penelitian yang digunakan adalah dengan melakukan overlay berbagai peta berbasis Geographic Information System (GIS). GIS mempunyai keistimewaan analisa yaitu analisa overlay dan analisa proximity dimana analisa overlay merupakan proses integrasi data dari lapisan-lapisan yang berbeda sedangkan analisa proximity merupakan analisa geografis yang berbasis pada jarak antar layer. Overlay merupakan proses penyatuan data dari lapisan layer yang berbeda. Secara sederhana overlay disebut sebagai operasi visual yang membutuhkan lebih dari satu layer untuk digabungkan secara fisik.

Metode overlay yang digunakan adalah Union Themes, Union yaitu menggabungkan fitur dari sebuah tema input dengan poligon dari tema overlay untuk menghasilkan output yang mengandung tingkatan atau kelas atribut. Data kuantitatif diperoleh dari hasil overlay berbagai peta disajikan dalam betuk tabulasi angka-angka hasil pengukuran atau penilaian peta, elanjutnya data tabulasi dideskripsikan sesuai dengan tema dan kriteria.

\section{HASIL DAN PEMBAHASAN}

\section{Hasil Overlay}

Konflik lahan atau yang lebih sering dikenal dengan tenurial di dalam kawasan hutan. Konflik tenurial merupakan masalah yang sangat kompleks karena melibakan berbagai pihak yang berkepentingan dalam memperebutkan lahan untuk dikuasai. Penguasaan lahan pada kawasan hutan terjadi secara kontiniu dengan adanya daya tarik sumberdaya alam yang ada dalam kawasan hutan untuk diekploitasi dan dikuasai akibat tekanan penduduk yang berada disekitar maupun jauh dari kawasan hutan tersebut. Tekanan terjadi karena kebutuhan lahan yang semakin meningkat dan ketersediaan lahan yang tetap.

Desakan dan tekanan pemanfaatan lahan pada kawasan hutan terjadi pada lindung, hutan produksi, hutan produksi konversi, hutan produksi terbatas, dan kawasan konservasi. Hasil overlay peta kawasan hutan dengan peta potensi konflik disajikan pada Tabel 1.

Tabel 1. Hasil Overlay Peta Kawasan Hutan

\begin{tabular}{rlrr}
\hline No. & \multicolumn{1}{c}{ Kawasan Hutan } & Luas (ha) & \multicolumn{1}{c}{ Persentase } \\
\hline 1 & Hutan Lindung & $107.528,98$ & 5,45 \\
2 & Hutan Produksi & $416.479,06$ & 21,11 \\
3 & Hutan Produksi Konversi & $941.939,45$ & 47,75 \\
4 & Hutan Produksi Terbatas & $422.119,53$ & 21,40 \\
5 & Konservasi Suaka Alam/Konservasi Pelestarian Alam & $84.631,64$ & 4,29 \\
\hline \multicolumn{2}{c}{ Jumlah } & $1.972 .698,67$ & 100,00 \\
\hline
\end{tabular}

Sumber: Lampiran Perda No. 10 Tahun 2018, diolah

Tabel diatas menunjukan bahwa kawasan hutan yang memilki potensi konflik adalah Kawasan Hutan Lindung, Hutan Produksi, Hutan Produksi Konversi, Hutan Produksi Terbatas, dan Konservasi Suaka Alam/Konservasi Pelestarian Alam secara berturut-turut sebesar 5,45\%, 21,11\%, 47,75\%, 21,40\%, dan 4,29\%. Kawasan hutan yang paling banyak berkonflik adalah pada kawasan Hutan Produksi Konversi mencapai 47,75\%, sedangkan yang paling sedikit adalah pada kawasan hutan Konservasi Suaka Alam/Konservasi Pelestarian Alam. Hal ini mengindikasikan bahwa masyarakat dan korporasi yang menguasai lahan dan terlibat konflik sebenarnya mengetahui bahwa lahan yang dikuasai memiliki potensi dapat dilepaskan dari kawasan hutan sehingga dengan berbagai cara dan upaya mempertahankan lahannya.

Kawasan ini merupakan kawasan hutan yang open akses, sehingga setiap orang dapat memasuki kawasan tersebut karena didukung dengan adanya sarana dan praarana milik pemerintah. kegiatan pembukaan lahan sebagai bentuk penguasaan lahan untuk pemukiman, peladangan dan perkebunan kelapa sawit milik masyarakat setempat dan masyarakat pendatang belum dilakukan enclave atau pelepasan dari kawasan hutan. 
Hasil overlay peta Pola Ruang Provinsi Riau, potensi konflik lahan terdapat pada Pola ruang Hutan Konservasi, Hutan Lindung, Hutan Lindung / Pariwisata, Hutan Produksi Konversi, Hutan Produksi Konversi / Hutan Adat, Hutan Produksi Konversi / Pariwisata, Hutan Produksi Terbatas, Hutan Produksi Terbatas / Hutan Adat, Hutan Produksi Terbatas / Pariwisata, Hutan Produksi Tetap, Hutan Rakyat, Industri, Kawasan Lindung Kawasan Lindung Resapan Air, Kawasan Peruntukan Lainnya, Lokasi Tambang, Pariwisata, Pemukiman, Perairan, Perkebunan Besar, Perkebunan Rakyat, Pertanian, dan Ruang Terbuka Hijau secara rinci disajikan pada Tabel 2.

Tabel 2. Hasil Overlay Peta Pola Ruang Provinsi Riau

\begin{tabular}{rlrr}
\hline No. & \multicolumn{1}{c}{ Pola Ruang } & Luas (ha) & Persentase \\
\hline 1 & Hutan Konservasi & $84.350,69$ & 4,28 \\
2 & Hutan Lindung & $106.892,77$ & 5,42 \\
3 & Hutan Lindung / Pariwisata & 569,90 & 0,03 \\
4 & Hutan Produksi Konversi & $868.481,47$ & 44,03 \\
5 & Hutan Produksi Konversi / Hutan Adat & 577,50 & 0,03 \\
6 & Hutan Produksi Konversi / Pariwisata & $2.940,44$ & 0,15 \\
7 & Hutan Produksi Terbatas & $413.896,17$ & 20,98 \\
8 & Hutan Produksi Terbatas / Hutan Adat & $1.905,81$ & 0,10 \\
9 & Hutan Produksi Terbatas / Pariwisata & $1.898,74$ & 0,10 \\
10 & Hutan Produksi Tetap & $413.331,77$ & 20,95 \\
11 & Hutan Rakyat & 979,51 & 0,05 \\
12 & Industri & $3.524,18$ & 0,18 \\
13 & Kawasan Lindung & 298,90 & 0,02 \\
14 & Kawasan Lindung Resapan Air & $7.942,13$ & 0,40 \\
15 & Kawasan Peruntukan Lainnya & 483,03 & 0,02 \\
16 & Lokasi Tambang & 588,02 & 0,03 \\
17 & Pariwisata & 161,96 & 0,01 \\
18 & Pemukiman & $7.008,65$ & 0,36 \\
19 & Perairan & $1.807,08$ & 0,09 \\
20 & Perkebunan Besar & $4.216,58$ & 0,21 \\
21 & Perkebunan Rakyat & $29.058,54$ & 1,47 \\
22 & Pertanian & $17.419,63$ & 0,88 \\
23 & Ruang Terbuka Hijau & $4.307,49$ & 0,22 \\
\hline & & Jumlah & 100,00 \\
\hline
\end{tabular}

Sumber: Lampiran Perda No. 10 Tahun 2018, diolah

Dari tabel diatas menunjukan bahwa potensi konflik lahan yang terbesar didominasi Hutan Produksi Konversi, Hutan Produksi Terbatas, dan Hutan Produksi Tetap secara berturut-turut sebesar 44,03.

$\%, 20,98 \%$, dan 20,95\%. Hal ini mengindikasikan bahwa konflik lahan terjadi didominasi pada areal Haka Pengusahaan Hutan (HPH), Eks HPH dan Hutan Tanaman Industri (HTI) baik yang sudah tidak aktif maupun aktif serta pada lahan konservasi seperti Taman Nasional Tesso Nilo.

Tabel 3. Hasil Overlay Peta Tutupan Lahan Tahun 2015

\begin{tabular}{rlrr}
\hline No. & \multicolumn{1}{c}{ Tutupan Lahan } & Luas (ha) & \multicolumn{2}{c}{ Persentase } \\
\hline 1 & Pemukiman & $13.735,47$ & 0,70 \\
2 & Perkebunan & $1.009 .915,96$ & 51,19 \\
3 & Pertanian Lahan Kering & $94.291,85$ & 4,78 \\
4 & Pertanian Lahan Kering Campur & $797.325,40$ & 40,42 \\
5 & Sawah & $56.097,88$ & 2,84 \\
6 & Tambak & $1.332,11$ & 0,07 \\
\hline & & $1.972 .698,67$ & 100,00 \\
\hline
\end{tabular}

Sumber: KLHK 2015, diolah

Selanjutnya berdasarkan penutupan lahan potensi konfik lahan terjadi pada peruntukan lahan Pemukiman, Perkebunan, Pertanian Lahan Kering, Pertanian Lahan Kering Campur, Sawah, dan Tambak secara berturutturut sebesar $0,70 \%, 51,19 \%, 4,78 \%, 40,42 \%, 2,84 \%$, dan 0,07\%. Potensi konflik berdasarkan tutupan lahan merupakan gambaran kondisi eksisting berupa lahan perkebunan kelapa sawit disusul pada Pertanian Lahan 
Kering Campur yang didalamnya didominasi perekabunan kelapa sawit rakyat (swadaya). Sedangkan potensi konflik yang terkecil berada pada tambak, dimana lahan tambak berada di wilayah pesisir yang saat ini beralih fungsi menjadi lahan perkebunan kelapa sawit.

Tabel diatas menunjukan bahwa potensi konflik lahan didominasi pada lahan perkebunan baik yang dimiliki oleh korporasi maupun mayarakat, konflik tersebut terjadi akibat oupasi lahan yang terjadi secara perlahan dan terus menerus oleh berbagai pihak (stakeholders) yang memiliki kepentingan terhadap kawasan hutan yang mempengaruhi ataupun dipengaruhi oleh tujuan pengelolaan hutan. Bagi masyarakat yang mengusai lahan di kawasan hutan menganggap fungsi hutan lebih bernilai ekonomis jika menjadi tanaman perkebunan dibandingkan dengan kondisi hutan akan tetapi masyarakat tidak dapat menikmati asilnya secara langsung.

Tabel 4. Hasil Overlay Peta Perizinan

\begin{tabular}{|c|c|c|c|}
\hline No. & Perizinan & Luas (ha) & Persentase \\
\hline 1 & \multirow{2}{*}{$\begin{array}{l}\text { Berijin } \\
\text { Tidak beriiin }\end{array}$} & $272.561,11$ & 13,82 \\
\hline 2 & & $1.700 .137,56$ & 86,18 \\
\hline \multicolumn{2}{|r|}{ Jumlah } & $1.972 .698,67$ & 100,00 \\
\hline
\end{tabular}

Sumber: Bappeda Provinsi Riau 2017, diolah

Dari tabel diatas menujukan bahwa pada potensi lahan yang berkonflik adalah didominasi lahan tidak berizin sebesar $86,16 \%$, sedangkan lahan yang memiliki izin sebesar $13,82 \%$. Penyebab utama timbulnya konflik adalah adanya perbedaan persepsi mengenai batas di dalam kawasan hutan karena tidak adanya kejelasan tata batas kawasan hutan. Selain itu konflik penggunaan kawasan hutan terjadi karena tumpeng tindihnya perizinan yang diberikan oleh pemerintah kepada masyarakat maupun korporasi.

Bagi masyarakat yang menguasai lahan pada kawasan hutan menganggap setiap hutan yang telah ditinggal atau tidak diusahakan oleh pemegang izin merupakan lahan yang terlantar dan dikuasai oleh negara, sedangkan masyarakat merupakan bagian dari warga negara. Sehingga penguasaan lahan sulit dibendung oleh pemrintah selaku regulator. Selain itu dukungan dari pihak pemerintah desa dan kecamatan mampu memperkuat argument bahwa lahan yang dikuasai dalam kawasan hutan bukan secara illegal, melainkan secara transparan melalui proses jual beli dari masyarakat adat maupun dari aparatur pemerintah.

\section{Dampak yang Ditimbulkan}

Isu dan tekanan internasional terus menerpa ekspor minyak kelapa sawit yang selalu dikaitkan kebakaran lahan, pembabatan hutan, dan pemanasan global sebagai akibat pembukaan lahan gambut. Amanat Peraturan Menteri Pertanian Nomor: 19/Permentan/OT.140/3/211 tentang Pedoman Perkebunan Kelapa Sawit Indonesia (Indonesian Sustainable Palm Oil/ISPO), dimana peraturan ISPO mengacu pada Roundtable on Sustainable Palm Oil (RSPO) dengan tujuan mensejahterakan pekebun dan berkembangannya industri hilir kelapa sawit.

Tahun 2015 luas perkebunan kelapa sawit 2.424.543,55 ha yang terdri dari perkebuan rakyat 1.354.501,55 ha, Perkebunan Pesar Nasional 84.854,00 ha, dan Perekbunan Swasta Nasional 985.188,00 ha. Berdasarkan data yang dihimpun oleh Asosisasi Petani Kelapa Sawit Indonesia tahun 2017 luas perkebunan kelapa sawit rakyat mencapi 2,44 juta hektar.

Bagi Pabrik Kelapa Sawit (PKS) yang telah memiliki sertifikasi ISPO tentu menjadi kendala bagi petani pekebun yang lahanya berada di kawaan hutan, PKS tersebut tidak membeli Tandan Buah Segar (TBS) dari petani yang berada di kawasan hutan karena akan diberikan sanksi. Jika diasumsikan luas lahan yang dikuasai masyarakat rata-rata $25 \mathrm{ha} / \mathrm{kk}$ maka terdapat $78.908 \mathrm{kk}$ masyarakat sebagai petani yang berada di kawasan hutan. Jika diasumsikan produksi rata-rata TBS perkebunan rakyat sebesar 2,67 ha/tahun, maka TBS yang tidak dapat akses pasar atau memiliki akses pasar dengan harga jauh dibawah harga pasar diperkirakan sebesar 4.533.510 ton/tahun.

\section{Solusi yang Diharapkan}

Penyelesaian konflik lahan dalam kawasan hutan diatur oleh Peraturan Presiden Republik Indonesia Nomor 88 Tahun 2017 Tentang Penyelesaian Penguasaan Tanah Dalam Kawasan Hutan Pasal 8 yaitu pola penyelesaian untuk bidang tanah yang dikuasai dan dimanfaatkan setelah bidang tanah tersebut ditunjuk sebagai kawasan hutan berupa: (a) mengeluarkan bidang tanah dalam kawasan hutan melalui perubahan batas kawasan hutan; (b) tukar menukar kawasan hutan; (c). memberikan akses pengelolaan hutan melalui program perhutanan sosial; atau (d) melakukan resettlement. 
Mekanisme penyelesaian tersebut tidak sepenuhnya dapat dilakukan, bagi lahan yang berada di kawasan lindung otomatis akan dilakukan resettlement tanpa kecuali. Bagi lahan yang dikuasai pada kawasan HP, HPT dan HPK akan dilakukan pelepasan dengan ketentuan harus memiliki kawasan hutan lebih dari 30\% dari luas wilayahnya.

\section{KESIMPULAN}

Hasil dari analisis data dan peta menunjukan bahwa faktor-faktor penyebab terjadinya konflik dalam pemanfaatan lahan untuk perkebunan kawasan hutan adalah: (a) ketidaksepahaman persepsi mengenai batas kawasan hutan antara masyarakat, korporasi dan pemerintah; (b) pada beberapa kawasan hutan sifatnya masih sebatas penunjukan belum ada tata batas dan penetapan kawasan hutan; (c) terdapat unsur ketidaktahuan masyarakat pada kawasan hutan; (d) terdapat unsur kesengajaan dengan memanfaatkan kelemahan pemerintah, korporasi dan masyarakat sekitar kawasan hutan untuk menguasai lahan; dan (5) terjadi keterlanjuran dalam pemberian izin oleh pemerintah dalam kawasan hutan.

Saran yang harus dilakukan pemerintah adalah memberikan kejelasan dan percepatan penyelesaian konflik dalam kawasan hutan dengan melakukan tatabas dan penetapan kawasan hutan. Instruksi Presiden No. 8 Tahun 2018 diharapkan dapat meredam dan mengatasi laju alih fungsi lahan menjadi perkebunan kelapa sawit dan sebagai alat untuk melepaskan Kawasan Hutan atau Pinjam Pakai Kawasan Hutan menjadi perkebuan kelapa sawit dengan mekanisme yang saling menguntungkan bagi pihak yang berkonflik.

\section{DAFTAR PUSTAKA}

Astuti, P. 2011. Kekerasan dalam konflik agraria: Kegagalan negara dalam menciptakan keadilan di bidang pertanahan. http://ejournal.undip.ac.id/index.php/foru m/article/download/3158/2834. Diakses 16 Mei 2018.

Arief, A. 2001. Hutan dan Kehutanan. Yogyakarta. Kanisius.

Aronoff, S. 1989. Geographic Information Systems: A Management Perspective. WDL Publications. Ottawa.

Barus, B., dan U.S. Wiradisastra. 2000. Sistem Informasi Geografi Sarana Manajemen Sumberdaya. Laboratorium Penginderaan Jauh dan Kartografi. Jurusan Tanah Fakultas Pertanian IPB. Bogor.

Colchester, M., dan S. Chao. 2011. Ekspansi kelapa sawit di Asia Tenggara. http://www.forestpeople.org Diakses 15 September 2018.

FAO. 1976. A Framework for Land Evaluation. FAO Soil Bulletin 52. Soil Resources Management and Conservation Service Land and Water Development Division.

https://www.google.co.id/search?q=walhi+nasional\&oq=Walhi\&aqs=chrome.3.014j69i60j0.4657j0j8\&sourceid= chrome\&ie=UTF-8 Diakses 11 September 2018.

Instruksi Presiden No. 8 Thn 2018 Tentang Penundaan dan Evaluasi Perizinan Perkebunan Kelapa Sawit Serta Peningkatan Produktivitas Perkebunan Kelapa Sawit.

Larson, A.M. 2012. Tenure rights and access to forests: A training manual for research. CIFOR. Bogor.

Mutolib, A., Yonariza, Mahdi, and H. Ismono. 2015. Local resistance to land grabbing in Dharmasraya District, West Sumatra Province. Paper presentedat The International Academic Conference Land Grabbing: Perspectives from East and Southeast Asia 2015, Chiang Mai University, Thailand, June 5-6, 2015.

Moleong, L.J. 2007. Metode Penelitian Kualitatif. Remaja Rosdakarya. Bandung.

Peraturan Kepala BPN RI No.3 tahun 2011 Tentang Pengelolaan Pengkajian dan Penanganan Kasus Pertanahan.

Peraturan Presiden No.9 Tahun 2016 Tentang Pelaksanaan Kebijakan Satu peta Tingkat Ketelitian Skala 1: 50.000.

Prahasta, E. 2003. Sistem Informasi Geografis: ArcView Lanjut 'Pemrograman Bahasa Script Avenue'. Bandung: Penerbit Informatika Bandung.

Prahasta, E. 2006. Membangun Aplikasi Web-based GIS dengan Map Server. Bandung: Bandung Informatika.

Rayes, L. 2007. Metode Inventarisasi Sumber Daya Lahan. Yogyakarta: Andi Yogyakarta.

Undang-Undang Republik Indonesia Nomor 41 Tahun 1999 Tentang Kehutanan.

Undang-Undang No. 41 Tahun 1999 Tentang Kehutanan. 
Undang-Undang No. 18 Tahun 2013 tentang Pencegahan dan Pemberantasan Perusakan Hutan.

Undang-undang No. 39 Tahun 2014 Tentang Perkebunan. 